\title{
PENGARUH PENERAPAN DISIPLIN BELAJAR TERHADAP PENINGKATAN PRESTASI BELAJAR MAHASISWI ASRAMA PUTERI SEKOLAH TINGGI PASTORAL ATMA REKSA ENDE
}

\author{
Viktoria Lelboy \\ Sekolah Tinggi Pastoral Atma Reksa Ende \\ Email: lelboyviktoria@stiparende.ac.id
}

\begin{abstract}
Abstrak
Tulisan ini berjudul "Pengaruh Penerapan Disiplin Belajar Terhadap Peningkatan Prestasi Belajar Mahasiswi di Asrama puteri Sekolah Tinggi Pastoral Atma Reksa Ende”. Tulisan ini dengan tujuan untuk mengetahui pengaruh penerapan disiplin serta peningkatan belajar Mahasiswi asrama puteri Sekolah Tinggi Pastoral Atma Reksa Ende. Disiplin, adalah melatih melalui pengajaran atau pelatihan”. Disiplin berkaitan erat dengan proses pelatihan yang dilakukan oleh pihak yang memberi pengarahan dan bimbingan dalam kegiatan pengajaran. Disiplin menjadi peranan penting dalam menciptakan lingkungan belajar yang kondusif serta proses pembentukan pembelajaran yang teratur sekaligus penting bagi keberhasilan prestasi akademik bagi diri anak dan melalui penerapan disiplin di asrama dapat membantu kemampuan setiap anak untuk mencapai tujuan dan harapan. Belajar bukanlah suatu tujuan tetapi merupakan suatu proses untuk mencapai tujuan, yang merupakan langkah-langkah atau prosedur yang ditempuh. Belajar adalah suatu proses perubahan tingkah laku individu melalui interaksi dengan lingkungan.pengertian ini menitikberatkan pada interaksi antara individu dengan lingkungan. Didalam interaksi inilah terjadi serangkaian pengalaman-pengalaman belajar. Prestasi belajar dipengaruhi oleh beberapa faktor, salah satunya yaitu disiplin belajar. Disiplin belajar bukan hanya tergantung pada faktor luar seperti orang tua, guru dan lingkungan tetapi yang paling penting disini adalah kedisiplinan diri sendiri. Cara disiplin belajar pada setiap mahasiswi untuk mencapai prestasi belajar berbeda-beda, seperti halnya disiplin mahasiswi asrama Stipar Ende.
\end{abstract}

Kata-kata Kunci: disiplin; belajar; prestasi belajar; asrama

\section{Pendahuluan}

Kehidupan manusia tidak terlepas dari pendidikan. Pendidikan dalam arti luas meliputi seluruh usaha manusia meningkatkan harkat kemanusiaannya. Dalam arti yang terbatas, pendidikan merupakan usaha mendewasakan anak. Usaha pendidikan mula-mula di dalam keluarga. Keluargalah yang pertama dan utama bertanggung jawab atas berlangsungnya pendidikan. Pendidikan mempunyai peranan penting bagi manusia terutama dalam menghadapi problema kehidupan. Hal ini dikarenakan pendidikan dapat mempengaruhi seluruh aspek kepribadian dan perkembangan kehidupan setiap manusia.

Pembangunan nasional di bidang pendidikan merupakan usaha mencerdasakan kehidupan bangsa dan meningkatkan kualitas manusia Indonesia dalam mewujudkan masyarakat yang maju, adil, dan makmur. Hal ini sejalan dengan rumusan tujuan pendidikan nasional yang tercantum dalam UndangUndang Republik Indonesia No. 20 Tahun 2003 tentang sistem pendidikan nasional pada pasal 3 yang menyebutkan bahwa: fungsi Pendidikan nasional mengembangkan kemampuan dan membentuk watak serta peradaban bangsa yang bermartabat dalam rangka mencerdaskan kehidupan bangsa, tujuannya untuk mengembangkan potensi peserta didik agar menjadi manusia yang beriman kepada Tuhan Yang Maha Esa, berakhlak mulia, sehat, berilmu, cakap, kreatif, mandiri, dan menjadi warga negara yang demokratis serta bertanggung jawab ${ }^{1}$.

Pendidikan dilihat sebagai faktor utama dan pertama dalam seluruh proses pembentukan pribadi seorang manusia. Peranannya membentuk pribadi seseorang menurut ukuran normatif. Menyadari akan hal tersebut, Asrama Puteri STIPAR Ende memperhatikan bidang pendidikan informal terutama

\footnotetext{
${ }^{1}$ Masnur Muslich., Pendidikan Karakter, Menjawab Tantangan Krisis Multidimensional, PT Bumi Aksara, 2015, hal. 17.
} 
pendampingan anak-anak asrama, sebab dengan sistem pendidikan, terutama pendampingan yang baik akan muncul generasi muda bangsa yang disiplin, berprestasi, berkualitas dan mampu menyesuaikan diri dalam hidup bermasyarakat, dan hidup menggereja di mana saja berada. Pendidikan di Asrama Puteri Stipar Ende merupakan sebuah jawaban terhadap perkembangan universal yang turut memengaruhi kedisiplinan belajar anak di zaman ini. Dengan demikian melalui pendidikan di asrama berupa penerapan disiplin belajar, perlu dikembangkan secara optimal demi mencapai kesejahteraan hidup di masa depan yang tidak hanya mementingkan salah satu ranah tetapi ketiganya saling kait mengait satu sama lain yakni kognitif, psikomotorik dan afektif.

Pendidikan bersifat universal artinya setiap orang perlu memiliki pendidikan. Setiap warga Negara Indonesia berhak mendapatkan pendidikan. Hal ini telah diatur dalam Undang-Undang Dasar Negara Republik Indonesia tahun 1945 Pasal 31 ayat 1 Sebuah negara dapat dilihat kemajuannya dari kualitas sumber daya manusia yang dihasilkan oleh Negara itu sendiri. Sumber daya manusia yang berkualitas tidak diperoleh dengan begitu mudah, tetapi perlu melewati sebuah proses yang membutuhkan waktu yang terus menerus dalam pendampingan sejak lahir sampai akhir hayatnya tanpa mengenal usia.

Pendidikan di Asrama Puteri Stipar Ende merupakan kunci utama untuk menghasilkan out come sumber daya manusia yang berkualitas dan unggul yang mampu bersaing dengan lembaga-lembaga lain dimana mahasiswi kelak nanti hidup bermasyarakat dan berkarya. Keberhasilan belajar dapat dikatakan berprestasi kalau itu dilihat dari faktor spiritual, pengetahuan, sikap, karakter, dan keterampilan. Semua capaian itu melalui proses belajar yang efektif, efisien, menyenangkan dan adanya saling kerja sama antara pemimpin dan mahasiswi. Undang-Undang Repuplik Indonesia No. 20 Tahun 2003 tentang sistem pendidikan Nasional bab I pasal 1 menjelaskan bahwa: Pendidikan adalah usaha sadar dan terencana untuk mewujudkan suasana belajar dan proses pembelajaran agar peserta didik secara aktif menumbuh kembangkan potensi dirinya untuk memiliki kekuatan spiritual keagamaan, pengendalian diri, kepribadian, kecerdasan, akhlak mulia, serta keterampilan sebagai seorang katekis nanti. Disisi lain, prestasi pendidikan tidak hanya dipandang dari aspek akademika saja, tetapi juga dapat dilihat pengembangan mahasiswi dalam aspek spiritual dan sosial. Seperti dalam tulisan. "pendidikan adalah usaha sadar dan sistematis yang dilakukan oleh orang-orang yang diserahi tanggung jawab untuk mempengaruhi peserta didik agar mempunyai sifat dan tabiat dengan cita-cita pendidikan"2. Oleh karena itu, peranan disiplin di asrama sangat penting dalam membentuk pribadi peserta didik yang bermutu dan berdaya guna sesuai dengan cita-cita pendidikan. Tanpa disiplin manusia tidak memiliki arah dan tujuan hidup yang jelas selain itu juga sebagai manusia merasa tidak tertinggal atau ketinggalan dari orang lain.

Pendamping dan mahasiswi merupakan dua komponen yang memiliki peranan yang penting dalam menjalankan penerapan disiplin belajar di asrama. Peranan mahasiswi di asrama sebagai penerima pengetahuan yang ditransferkan dari pendamping. Peranan pendamping sama dengan tugas seorang guru sebagai penyadar, pendamping, komunikator, motivator sebagai pemberi inspirasi dan dorongan, sahabat yang dapat memberikan nasihat-nasihat dan pembimbing dalam pengembangan sikap dan tingkah laku sekaligus sebagai pendamping. Dari pernyataan yang ada maka jelas bahwa pendamping asrama adalah penentu terciptanya kegiatan pendidikan yang efektif, efisien dan bermakna sehingga mencapai prestasi belajar yang baik yang terbukti pada kartu hasil studi anak. Prestasi belajar yang baik tergantung dari keseriusan dan kedisiplinan diri dalam memanfaatkan waktu, selain itu juga kembali pada kemauan mahasiswi untuk meningkatkan ingin tahu tentang hal baru³ .

Pada realitas, keberhasilan prestasi belajar mahasiswi dipengaruhi oleh beberapa faktor seperti faktor internal dan eksternal. Faktor internal berasal dari dalam diri mahasiswa sendiri, yang meliputi intelegensi, minat, motivasi, kesehatan dan cara belajar, sedangkan faktor eksternal berasal dari luar diri mahasiswi yang meliputi keluarga, lingkungan sekolah, dan lingkungan masyarakat. Selain faktor-faktor yang telah dipaparkan, juga ada faktor lain yang memiliki peranan penting dalam kegiatan

\footnotetext{
${ }^{2}$ Munib Achmad., dkk. Pengantar Ilmu Pendidikan Semarang: Unnes Press. 2011, hal. 34.

${ }^{3}$ Hamalik Oemar, Proses Belajar Mengajar, Bandung 200, hal. 124.
} 
belajar seseorang yaitu disiplin belajar. Disiplin belajar sangat berpengaruh pada seseorang pelajar atau mahasiswa/i untuk memperoleh prestasi belajar yang lebih baik. Sikap dan perlilaku disiplin tidak terbentuk dengan sendirinya dalam diri seseorang tetapi membutuhkan waktu dan proses yang cukup panjang. Disiplin akan terwujud melalui pembinaan terus menerus yang dilakukan oleh orang tua, yang berlanjut di lingkungan sekolah dan bermasyarakat. Tempat utama dan paling utama bagi perkembangan disiplin belajar dan perkuliahan seorang mahasiswa/i adalah keluarga dan lingkungan pendidikan di sekolah karena disiplin belajar tidak hanya terbentuk secara otomatis melainkan oleh faktor lingkungan. Oleh karena itu untuk meraih prestasi belajar yang baik, setiap orang perlu menanamkan belajar yang baik dan teratur. Prestasi beajar tidak hanya ditentukan oleh kecerdasan intelektual belaka, tetapi juga oleh disiplin belajar. Mahasiswa yang memiliki disiplin tentu menunjukkan sikap keteraturan dan ketaatannya dalam belajar yang tanpa paksa dan dan tekanan dari faktor luar ${ }^{4}$.

Kata disiplin "sebagai suatu kondisi yang tercipta dan terbentuk dari serangkaian perilaku yang menunjukkan nilai ketaatan, kepatuhan, kesetiaan, keteraturan atau ketertiban". Apabila kedisiplinan belajar dipatuhi dengan sesungguhnya dan dilaksanakan cecara continu oleh setiap mahasiswa maka mahasiswa akan mendapatkan prestasi belajar yang baik pula, selain itu juga dapat menghindarkan diri dari rasa malas, dan menumbuh kembangkan kegairahan mahasiswa dalam belajar. Displin belajar ini dapat dilakukan pada dua tempat yang salin mendukung yaitu asrama dan sekolah. Disiplin belajar di kampus diwujudkan dalam bentuk aktif dalam pembelajaran, mengerjakan tugas yang diberikan oleh dosen, aktif masuk kuliah dan lain-lain. Sedangkan disiplin belajar di rumah atau di asrama mahasiswi secara terus mnerus dan secara teratur tanpa mendapatkan tekanan dan paksaan dari siapapunn dan situasi apapun sehingga dapat belajar dengan leluasa tanpa tekanan. Namun berdasarkan kenyataan di lapangan, nampaknya bahwa mahasiswi belum sepenuhnya memahami pentingnya disiplin belajar. Terkadang mahasiswi menganggap belajar sebagai hal yang membosankan, dan menjenuhkan belajar, baik di rumah maupun di sekolah.

Kenyataan lain yang mempengaruhi sikap mahasiswi menjadi malas belajar adalah tergantung juga aktifitas kegiatan pembelajaran yang dilakukan oleh dosen yang terkadang kurang menarik bagi mahasiswi sehingga merasa malas untuk belajar. Padahal pada hakekatnya, disiplin merupakan kunci kesuksesan seseorang. Ketika kedisiplinan sudah ditanamkan pada diri mahasiswi dan dihayati dengan sesungguhnya maka akan melakukan segala sesuatu yang berkaitan dengan kehidupannya tertutama berlajar tanpa merasa beban dan melakukannya tidak dengan terpaksa demi mencapai hasil yang memuaskan.

\section{Disiplin}

Pada bagian kajian pustaka ini penulis akan mencoba membahas beberapa hal yang berkaitan dengan tema dengan beberapa sub tema sebagai berikut: kajian teori ini akan berbicara tentang teori-teori yang berhungan dengan penelitian ini, antara lain Disiplin, belajar, disiplin belajar, prestasi belajar dan pengaruh disiplin belajar terhadap prestasi belajar.

\subsection{Pengertian Disiplin}

Kata disiplin berasal dari bahasa latin "Disiplina" yang merujuk kepada kegiatan belajar dan mengajar. Istilah tersebut boleh dapat dikatakan hampir sama dalam istilah bahasa Inggris "Disciple" yang mengandung arti mengikuti orang untuk belajar dibawah bimbingan seorang pemimpin ${ }^{5}$. Seiring dengan itu adapun pendapat dari para ahli lain diantaranya Khalasa, menjelaskan bahwa "disiplin adalah melatih melalui pengajaran atau pelatihan". Disiplin berkaitan erat dengan proses pelatihan yang dilakukan oleh pihak yang memberi pengarahan dan bimbingan dalam kegiatan pengajaran. Sedangkan menurut Koesoema, istilah disiplin terutama mengacu pada proses pembelajaran. Disipiplin sesungguhnya selalu dikaitkan dengan konteks relasi dalam jumlah besar yang berkisar dari 15-45 murid

\footnotetext{
${ }^{4}$ Tulus Tueu., Peran Disiplin pada Perilaku dan Prestasi Siswa. Jakarta: Grasindo, 2004, 31.

${ }^{5}$ Ibid., hal. 30.
} 
degan soerang guru serta lingkungan yang menyertainya, seperti tata peraturan, tujuan dari sebuah pembelajaran, dan pengembangan kamampuan dari murid-murid bimbingan guru. Sementara itu menurut Njoroge \& Nyabuto disiplin adalah unsur yang sangat penting bagi keberhasilan prestasi akademik sessorang ${ }^{6}$. Disiplin asrama memainkan peran penting dalam pencapaian harapan dan tujuan pembelajaran, rasa tanggung jawab peserta didik di asrama dan juga pendamping asrama.

Istilah disiplin dalam bahasa Indonesia sering juga terkait dan menyatu dengan istilah tata tertib dan ketertiban. Istilah ketertiban mempunyai arti kepatuhan seseorang dalam mengikuti dan mentaati sebuah peraturan atau tata tertib dalam hidup bersama, atau dalam sebuah kelompok, dan tata tertib ini karena adanya pihak kedua yang mendorong dirinya untuk demi kebaikan dalam kelompok itu juga bagi diri sendiri. Terlepas dari itu istilah disiplin sebagai kepatuhan dan ketaatan yang muncul karena adanya kesadaran dari diri sendiri untuk menjadi orang yang baik dan berguna bagi Tuhan, Gereja dan Orang tua. Hal ini sesuai dengan pendapat Zuiriah, yang menyatakan bahwa seseorang dikatakan berdisiplin apabila melakukan pekerjaan dengan tertib dan teratur sesuai dengan waktu dan tempatnya serja dikerjakan dengan penuh kesaaran, ketekunan, keikhlasan atau tanpa paksaan dari pihak siapapun. Berdasarkan penejalasan diatas, penulis menyimpulkan bahwa disiplin adalah suatu kepatuhan atau ketaatan seseorang terhadap peraturan dan tata tertib yang ditetapkan bersama dalam kelompok, dan atas dorongan serta kesadaran yang muncul dalam diri setiap peserta anak didik di asrama yang kemudian dapat diterapkan tanpa adanya paksaan atau tekanan dari pendamping asrama dan pihak siapapun yang berkecimpung dalam pendampingan asrama. Apabila dikaitkan dengan seluruh kegiatan pendidikan di asrama, disiplin merupakan salah satu faktor yang efektif dalam pembelajaran ${ }^{7}$. Disiplin menjadi peranan penting dalam menciptakan lingkungan belajar yang kondusif serta proses pembentukan pembelajaran yang teratur sekaligus penting bagi keberhasilan prestasi akademik bagi diri sendiri. Dengan adanya penerapan disiplin di asrama dapat membantu kemampuan setiap orang untuk mencapai tujuan yang telah ditetapkan.

\subsection{Macam-macam Disiplin}

Menurut Tu'u, ada macam-macam disiplin yang perlu diketahui bersama antara lain; pertama, disiplin otoritarian, yang ifatnya memaksa kehendak orang lain tanpa mempertimbangkan apa dampaknya yang diterapkan kepada orang lain. Dalam disiplin ini, peraturan diberlakukan sangat ketat dan secara rinci. Dalam hal ini setiap orang yang berada dalam lingkungan disiplin tersebut diminta untuk mematuhi dan manaati peraturan yang berlaku. Bila dalam kenyataan keseharian ada yang melanggar, maka mendapatkan sanksi atau hukuman sesuai pelanggarannya. Sebaliknya, apabila seseorang mematuhi peraturang dengan baik sesuai tuntutan kadang kurang mendapat penghargaan karena disiplin otoritarian sudah menjadi sebuah kewajiban bersama untuk mencapai sebuah tujuan bersama. Kedua, displin permisif, disiplin ini bersifat membebaskan. Dimana dalam penerpan disiplin ini setiap orang diberikan kebebasan untuk boleh mengambil keputusan sendiri dan bertindak sesuai dengan keinginan hatinya. Karena itu pada disiplin ini tidak ada sanksi yang diberikan bila seseorang tidak mematuhi aturan bersama dengan demikian akan menimbulkan dampak kebingungan dan kebimbangan. Akibat dari penerapan disiplin ini anak tidak tahu membedakan mana yang diperbolehkan mana yang tidak diperbolehkan dan bahkan mana yang dilarang dan tidak dilarang. Ketiga, disiplin demokratis, Pendekatan disiplin demokratis dilakukan dengan memberi penjelasan, adanya diskusi bersama dan penalaran untuk membantu anak agar anak lebih memahami alasan mengapa anak diharapkan mematuhi dan mentaati peraturan yang ada $^{8}$. Penerpan metode ini lebih menekankan pada aspek edukatif, bukan sanksinya. Sementara itu tujuan dan manfaat dari sanksi disiplin yang diterapkan kepada setiap anak yang melanggar hanya semata-mata sebagai upaya menyadarkan, mengoreksi dan memperbaiki, serta mendidikan sehingga menjadi anak yang lbih baik dari sebelumnya. Oleh karena itu disiplin demokrasi, anak memiliki tanggung jawab dan kemandirian yang tinggi.

\footnotetext{
${ }^{6}$ http://mariatulannisa.blogspot.com/2014/01/teori-prestasi-belajar.html. Diakses di Ende, 20 Januari 2021.

${ }^{7}$ Zuriah, Nurul, Metodologi Penelitian Sosial dan Pendidikan. Jakarta: Bumi , 2011, hal. 83

${ }^{8}$ Tulus Tu'u., Op.Cit., hal. 44-46.
} 
Sementara itu menjelaskan juga mengenai macam-macam disiplin yakni: pertama, Disiplin Otoriter, disiplin ini bersifat otoriter, orang tua dan pengasuh atau pun pembimbimg menetapkan peraturan-peraturan dan secara langsung mau menyatakan bahwa anak harus mematuhi peraturanperaturan tersebut. Dalam hal ini tidak adanya kompromi dan anak tidak diberikan kesempatan untuk mengemukakan pendapat mengenai adil tidaknya peraturan-peraturan yang diberikan. Kedua, Disiplin yang lemah Filsafat, yang medasari teknik disiplin adalah melalui akibat dari perbuatannya sendiri, anak akan belajar bagaimana berperilaku secara social. Dengan demikian, tidak diajarkan peraturan-peraturan, anak tidak dihukm karena melakukan dan tidak diberi hadiah kepada anak yang bersikap dan berperilaku baik. Ketiga, Displin demokratis, Disiplin ini menekankan pada anak agar naka mengetahui alasan mengapa peraturan-peraturan yang dilakukan dan memperoleh kesempatan mengemulan pendapatnya sendiri bila anak menganggap peraturan-peraturan itu tidak adil ${ }^{9}$. Disini dikemukakan bahwa bagi anak yang melanggar peratruan akan diberikan hukuman dan bagi anak yang berperilaku atau bersikap baik diberikan support berupa hadiah. Di lain sisi ada juga disiplin individu dan sosial. Pertama, disiplin individu. Disiplin individu adalah disiplin yang dikembangkan dan dimiliki secara alamiah oleh seseorang disiplin dikembangkan karena adanya kemampuan dan kemauan sendiri dalam hal mengendalikan diri.disiplin lahir dari dalam diri sendiri karena adanya kesadaran dan kemauan dari diri untuk mengikuti dan menjalani aturan yang diberlakukan dimana pun berada dan dalam situasi apapun. Kedua, Disiplin sosial. Disiplin in merupakan perwujudan adanya disiplin pribadi yang berkembang melalui kewajiban pribadi dalam individu dan karakter ${ }^{10}$.

\subsection{Unsur-unsur Disiplin}

Dalam karya tulisan menggambarkan beberapa unsur disiplin menjadi tiga bagian yaitu pertama, peraturan dan hukum yang berfungsi sebagai dasar dan pedoman bagi penilaian yang baik. Kedua, Hukuman bagi pelanggaran peraturan dan hukum. Hukuman yang diberikan berupa sanksi yang mempunyai nilai pendidikan dan tidak hanya bersifat menakut-nakuti saja, akan tetapi bersifat menyadarkan anak agar tidak mengulangi perbuatan yang sama ketiga, hadiah untuk perilaku yang baik atau usaha untuk berperilaku sosial yang baik. Hadiah dapat diberikan dalam bentuk prnghargaan agar anak lebih termotivasi untuk berbuat baik ${ }^{11}$.

\subsection{Pentingnya Disiplin}

Ketika berbicara tentang pentingnya disiplin tentu sangat menarik bagi setiap orang yang mau meraih sebuah keberhasilan, karena disiplin mempunyai peranan yang sangat penting untuk membentuk setiap pribari yang berciri keunggulan. Disiplin sangat dibutuhkan oleh setiap individu maupun kelompok seperti dalam kehidupan berasrama perlu adanya sebuah kedisiplinan agar setiap anak yang hidup dan belajar di asrama memliki pekerti dan karakter yang baik. Budi pekerti dan karakter yang baik bagi seorang anak tentu membutuhkan proses seperti latihan berdisiplin secara terus menerus. Seiring dengan itu juga mengemukakan bahwa disiplin itu penting karena dengan disiplin yang munul dari dari sendiri anak akan berhasil delam belajarnya. Sebaliknya, anak yang kerap kali melanggar ketentuan di asrma pada umumnya terhambat optimalisasi potensi dan prestasinya. Ketika seorang anak hidup di asrama tanpa disiplin yang baik, suasana asrama menjadi kurang kondusif bagi kegiatan pembelajaran maupun kehidupan spiritualnya. Apabila dilihat dari segi positif, disiplin memberi dukungan lingkungan yang tenang dan tertib bagi proses pembelajaran. Disatu sisi pada era globalisasi ini anak tidak mau hidup dalam tekanan karena aturan kedisiplinan yang mengikat tetapi pada sisi lain orang tua senantiasa berharap agar dibiasakan dengan norma-norma nilai kehidupan dan disiplin. Karena dengan pemikiran orang tua bahwa dengan adanya aturan disiplin anak menjadi bertumbuh menjadi individu yang tertib, teratur dan disiplin hidup dikemudian hari.

\footnotetext{
${ }^{9}$ Hurlock, Elizabeth B. Psikologi Perkembangan Suatu Pendekatan Sepanjang Rentang Kehidupan (Edisi 5)
} 1980. Diterjemahkan oleh Istiwidayanti dan Soedjarwo. 2008. Jakarta: Erlangga. 99, 129.

${ }^{10}$ Tulus Tu'u, Op. Cit. hal. 46.

${ }^{11}$ Hurlock Elizabeth B., Op. Cit., hal. 92. 
Disiplin sangat penting bagi setiap individu karena itu disiplin menjadi salah satu kunci dari sebauh kesuksesan seseorang. Maman Rachman dalam (Tu'u) mengatakan pentingnya disiplin bagi anak sebagai berikut

Pertama, Memberi dukungan bagi terciptanya perilaku yang tidak menyimpang. Kedua. Membantu siswa memahami dan menyesuaikan diri dengan tuntutan lingkungan. Ketiga, Cara menyelesaikan tuntutan yang ingin ditunjukkan peserta didik terhadap lingkungannya. Keempat, Untuk mengatur keseimbangan keinginan individu satu dengan individu lainnya. Kelima, Menjauhi siswa melakukan hal-hal yang dilarang sekolah. Keenam, Mendorong siswa melakukan hal-hal yang baik dan benar. Ketuju, Peserta didik belajar hidup dengan kebiasaan-kebiasaan yang baik, positif dan bermanfaat baginya dan lingkungannya ${ }^{12}$

Selanjutnya Pasternak, menjelaskan pentingnya disiplin untuk:

Menjaga anak-anak tetap terjaga dan aman. 2. Mengajarkan anak untuk memikirkan orang lain termasuk orang tuanya. 3. Memberikan sebuah kondisi yang bisa diprediksi dan karenanya aman bagi mereka jika berada di sana. 4. Membantu anak-anak mengembangkan kemandirian yang konstruktif. 5 . Memperjelas perbedaan antara perilaku yang diterima dan yang tidak diterima. 6. Menunjukkan bahwa setiap perbuatan memiliki akibat. 7. Membantu agar anak dengan mudah berhadapan dengan beragam kelompok, misalnya keluarga atau sekolah ${ }^{13}$.

Berdasarkan pendapat para ahli di atas, maka dapat di simpulkan bahwa disiplin penting bagi kehidupan manusia terutama bagi anak yang hidup dan tinggal di asrama. Disiplin memberikan sumbangan yang besar terhadap keberhasilan anak dalam mencapai tujuan belajar dan untuk mencapai kematangan kehidupan spiritualnya. Dengan adanya disiplin dalam belajar yang didukung dengan kematangan hidup spiritual, maka anak dari waktu ke waktu akan menyadari betapa pentingnya belajar secara teratur dan mengikuti kegiatan rohani dengan teratur pula.

\subsection{Manfaat Disiplin}

Manfaat dari disiplin di asrama sangat dibutuhkan oleh setiap anak dan perlu ditanamkan pada diri setiap anak sejak dini dan selama tinggal di asrama. Disiplin asrma menjadi prasyarat bagi proses pembentukan sikap, perilaku, dan tata kehidupan berdisiplinan yang akan menghantar seorang anak dalam belajar dan menjadi seorang religius yang baik di kemudian hari. Dalam proses pembentukan kepribadian setiap anak tentu ada manfaatnya seperti: pertama, menata kedisiplinan dalam kehidupan bersama untuk menyadarkan setiap anak bahwa perlu mengharai orang lain dengan cara menaati dan mematuhi peraturan yang berlaku. Ini juga membnina setiap anak untuk membangun hubungan relasi social dengan sesama menjadi baik dan lancar. Kedua, membangun kepribaidan merupakan merupakan sebuah proses pembentukan diri secara keseluruhan, tingkah laku dan pola hidup anak yang tercermin dalam penampilan, perkataan dan perbuatan sehari-hari. Proses pembentukan kepribadian ini biasanya juga di pengaruhi oleh faktor lingkungan, keluarga, pergaulan, masyarakat, dan sekolah. Proses pembentukan ini tidak begitu mudah dalam waktu yang singkat, tentu melalui sebuah proses yang panjang melalui berbagai latihan. Sebaliknya yang sudah terbiasa dengan aturan yang disiplin perlu adanya pendampingan terus menerus agar tidak terprovokasi dengan yang lain dalam kebersamaan. Ketiga, manfaat dari disiplin asrama adalah untuk membentuk pribadi anak agar belajar dan tahu hidup bersosial dan solider dengan orang lain ketika hidup bermayarkat nanti selain itu di bentuk untuk tahu bertanggungjawab dengan diri sendiri, kepada Tuhan, Orang tua, bangsa dan Gereja.

\section{Belajar}

Ada beberapa ahli telah mencoba merumuskan dan membuat tafsirannya tentang "belajar". Seringkali pula perumusan dan tafsiran itu berbeda satu sama lain. Namun ada beberapa hal yang perlu dilihat bersama tentang pengertian belajar antara lain: pertama, Belajar adalah modeifikasi atau

\footnotetext{
12 Tulus Tu'u., Op. Cit., hal. 35.

${ }^{13}$ Pasternak Rachel., Discipline, learning skills and Academic Achievement, 2013, Hal. 144.
} 
memperteguh kelakuan melalui pengalaman. Artinya belajar merupakan suatu proses, suatu kegiatan dan bukan suatu hasil atau tujuan. Belajar bukan hanya mengingat, akan tetapi lebih luas dari itu yakni mengalami. Hasil belajar bukan suatu penguasaan hasil latihan melainkan pengubahan kelakuan. Kedua, Seiring dengan penjesan point 1 , ada pula tafsiran lain tentang belajar yang menyatakan, bahwa belajar suatu proses perubahan tingkah laku individu melalui interaksi dengan lingkungan. Ketiga, Dibandingkan dengan pengertian pertama maka jelas tujuan belajar itu prinsipnya sama, yakni perubahan tingka laku, hanya berbeda cara atau usaha pencapaiannya. Belajar adalah Suatu Proses. Bulajar bukan suatu tujuan tetapi merupakan suatu proses untuk mencapai tujuan.

\subsection{Ciri-ciri belajar}

William Burton menyimpulkan uraiannya yang cukup panjang; Pertama, Proses belajar ialah pengalaman, berbuat, meraksi, dan melampui, kedua, Proses itu melalui bermacam-macam ragam pengalaman, ketiga, Pengalaman belajar secara maksimum bermakna bagi kehidupan anak, keempat, Pengalaman belajar bersumber dari kebutuhan dan tujuan anak sendiri yang mendorong motivasi kontinu, kelima, Proses belajar dan hasil belajar disyarati oleh hereditas dan lingkungan, keenam, Proses belajar dan hasil belajar secara materiil dipengaruhi oleh perbedaan-perbedaan individual di kalangan anak-anak, ketujuh, Proses belajar berlangsung secara efektif apabila pengalaman-pengalaman dan hasil-hasil yag diinginkan disesuaikan dengan kematangan anak ${ }^{14}$.

Berdasarkan pendapat ahli di atas, dapat disimpulkan bahwa belajar merupakan usaha sadar yang dilakukan oleh seseorang untuk memperoleh perubahan perilaku ke arah yang lebih baik sebagai hasil dari pengalamannya sendiri. Perubahan tersebut tidak hanya dari segi perilakunya, akan tetapi mencakup tiga ranah yaitu afektif, kognitif dan psikomotorik. Jadi, dapat dikatakan belajar tersebut berpengaruh terhadap seluruh kemampuan individu.

\subsection{Disiplin Belajar}

Berdasarkan pengertian disiplin dan belajar yang telah diuraikan di atas, maka yang dimaksud disiplin belajar dalam tulisan ini adalah serangkaian sikap, tingkah laku anak yang menunjukkan ketaatan dan kepatuhannya untuk belajar secara teratur baik di asrama, di sekolah maupun di rumah atas dasar kesadaran diri anak untuk belajar tanpa adanya paksaan dari pihak manapun. Disiplin belajar berfungsi untuk menerapkan cara belajar yang baik sehingga anak dapat mencapai tujuan belajar yang diinginkan. Disiplin belajar dapat berlangsung di asrama, sekolah maupun rumah secara rutin. Apabila anak sudah memiliki disiplin belajar yang baik, maka hasilnya pun akan terlihat dari segi perilaku dan prestasinya. Disiplin belajar akan membuat seseorang memiliki kecakapan mengenai cara belajar yang baik dan pembentukan watak yang baik pula. Cara belajar yang baik adalah suatu kecakapan yang dapat dimiliki oleh setiap orang dengan jalan latihan. Tetapi, keteraturan dan disiplin harus dikembangkan dengan penuh kemauan dan kesungguhan.

\section{Pengertian Prestasi Belajar}

Prestasi adalah hasil yang dicapai sacara individu atau kelompok atas usaha dan kegiatan yang telah diperjuangkan. Tanpa sebuah kegiatan dan perjuangan, prestasi tidaklah dapat dicapai begitu saja. Bahwa pada dasarnya, prestasi dan hasil belajar itu sama, dalam arti prestasi belajar karena hasil belajar.

Menurut Suryabrata dalam prestasi belajar adalah hasil yang telah dicapai seseorang dalam belajar. Sementara menurut Haryanto, "prestasi belajar adalah hasil yang dicapai oleh seseroang setelah ia melakukan perubahan belajar, baik di sekolah maupun di luar sekolah. Setelah melihat pendapat para ahli diatas, maka dapat disimpulkan bahwa belajar adalah hasil yang diperoleh anak setelah melakukan

\footnotetext{
${ }^{14}$ Hamalik Oemar, Proses Belajar Mengajar, Bandung 2001, hal. 27-29.
} 
kegiatan belajar. Hasilnya berupa penilaian baik nilai angka maupun nilai huruf yang diperoleh anak dalam kurun waktu tertentu ${ }^{15}$.

\subsection{Faktor-faktor positif yang Mempengaruhi Prestasi Belajar}

Prestasi belajar adalah hasil interaksi dari berbagai faktor, baik internal maupun eksternal yang turut berpengaruh satu sama lain. Menurut Darmadi, faktor-faktor yang mempengaruhi prestasi belajar, terdiri dari beberapa bagian antara lain:

1.Faktor eksternal, Faktor eksternal yang mempengaruhi prestasi belajar siswa dapat digolongkan ke dalam faktor sosial dan non-sosial. Faktor sosial menyangkut hubungan antar manusia yang terjadi dalam berbagai situasi sosial yaitu keluarga, sekolah, teman dan masyarakat. Sedangkan faktor non-sosial mencakup lingkungan alam dan fisik. 2. Faktor internal Faktor internal yang mempengaruhi prestasi belajar siswa meliputi intelegensi, minat, sikap dan motivasi. Selain itu, waktu dan kesempatan juga mempengaruhi prestasi belajar siswa karena setiap orang memiliki waktu dan kesempatan yang berbeda sehingga akan berpengaruh terhadap kemampuan siswa ${ }^{16}$.

Sementara, Tu'u menjelaskan faktor-faktor yang mempengaruhi prestasi belajar siswa meliputi:

1. Faktor kecerdasan. Tinggi rendahnya kecerdasan yang dimiliki seorang siswa sangat menentukan keberhasilannya mencapai prestasi belajar, termasuk prestasi-prestasi lain sesuai macam-macam kecerdasan yang menonjol pada dirinya. 2. Faktor bakat. Bakat adalah kemampuan yang ada pada seseorang yang dibawanya sejak lahir dan diterima sebagai warisannya dari orang tua. 3. Faktor minat dan perhatian. Minat adalah kecenderungan yang besar terhadap sesuatu. Perhatian adalah melihat dan mendengar dengan baik dan teliti terhadap sesuatu. 4. Faktor motif. Motif adalah dorongan yang membuat seseorang berbuat sesuatu. Motif selalu mendasari dan mempengaruhi setiap usaha seseorang untuk mencapai tujuan yang diinginkan. Apabila dalam belajar peserta didik mempunyai motif yang besar dan kuat, maka akan memperbesar usahanya untuk mencapai prestasi yang diharapkan. 5. Faktor cara belajar. Cara belajar yang efisien memungkinkan mencapai prestasi lebih tinggi dibandingkan dengan cara belajar yang tidak efisien. 6. Faktor lingkungan keluarga. Lingkungan keluarga sangat mempengaruhi prestasi belajar siswa karena sebagian besar waktu seseorang berada di rumah. Faktor sekolah. Sekolah adalah lingkungan kedua yang berperan besar memberi pengaruh pada prestasi belajar siswa. Kondisi lingkungan sekolah diharapkan kondusif agar siswa terdorong untuk giat belajar ${ }^{17}$.

Berdasarkan kedua pendapat ahli di atas tentang faktor yang mempengaruhi prestasi belajar, penulis menekankan pada faktor disiplin belajar sebagai faktor yang akan berpengaruh pada pribadi dalam hal positip dan juga merupakan faktor yang utama. Disiplin belajar merupakan faktor penunjang yang mempengaruhi kegiatan belajar dan pendidikan di asrama. Disiplin belajar dan kegiatan rutinitas asrama memerlukan latihan secara rutin dan teratur sehingga anak tidak memiliki rasa terpaksa dalam melakukan kegiatan belajar baik di sekolah maupun asrama.

\subsubsection{Faktor-faktor yang Memengaruhi Menurunnya Prestasi Belajar}

Berdasarkan pengamatan yang dilihat pada mahasiswi asrama puteri STIPAR Ende selama harihari efektif perkuliahan berlangsung, kedisiplinan tidak begitu mudah dihayati oleh mahasiswi berkaitan dengan belajar dari rumah akibat pandemic Covid-19, di lain sisi masih ada faktor yang turut memengaruhi prestasi belajar mahasiswi antara lain motivasi belajar menurun karena kesulitan yang dialami yakni: pertama, BDR yang kadang tidak dipahami dengan baik karena tidak adanya penjelasan langsung dari dosen, kedua, kurang adanya perhatian dari orang tua karena orang tua tidak bersama di rumah sebagai keluarga (merantau), ketiga, fasilitas belajar, tergantung dari (Hp yang dimiliki, Wifi dan

${ }^{15}$ Haryanto., Pengertian Prestasi Belajar. http://belajarpsikologi.com/pengertian-prestasi-belajar/. Diunduh di Ende, 10 Januari 2021.

${ }^{16}$ Darmadi Hamid, Kemampuan Dasar Mengajar Landasan Konsep dan Implementasi, Bandung: Alfabeta, 2010, hal. 188-189.

${ }^{17}$ Tulus Tu'u., Op.Cit., hal. 78-81. 
jaringan), keempat, tidak ada keinginan untuk belajar karena adanya paksaan dari orang tua agar anak harus melanjutkan studi ke jenjang perguruan tinggi STIPAR Ende bukan di universitas lain. Disiplin belajar adalah salah satu faktor yang cukup dominan bagi mahasiswi untuk mencapai prestasi belajar yang memuaskan. Mahasiswi asrama Puteri Stipar memiliki tingkat disiplin belajar yang tidak sama, bahwa ada yang memliki disiplin belajar yang tinggi, sedang dan rendah. Hal ini disebabkan oleh setiap mahasiswi yang memiliki peradaban cara belajar, motivasi, perhatian orang tua dan paling penting dan utama adalah kesadaran dari diri sendiri terhadap disiplin belajar

\subsection{Pengaruh Disiplin Belajar terhadap Prestasi Belajar anak Asrama}

Pengaruh disiplin belajar terhadap prestasi mahasiswi asrama Sekolah Tingggi Pastoral Atma Reksa Ende menjadi faktor utama dalam keberhasilan akademica di Sekolah Tinggi Pastoral Atma Reksa Ende. Prestasi belajar menjadi akibat dari disiplin belajar. Dengan demikian disiplin belajar berarti sikap keteraturan anak dalam belajar yang dibantu dengan aturan-aturan bersama, artinya anak suda dibiasakan belajar dengan teratur tanpa adanya paksaan dari pihak lain. Secara teori, apabila siswa sudah mampu menanamkan disiplin belajar dengan baik, maka prestasi belajarpun akan meningkat dengan sendirinya. Karena itu disiplin asrama menjadi salah satu faktor dominan dalam memengaruhi prestasi belajar anak. Dalam hal ini Gie, mengemukakan bahwa dalam usaha apapun juga, keteraturan dan disiplin akan tetap merupakan kunci memperoleh hasil yang baik dan memuaskan. Ketika seorang anak memahami aturan dan memiliki disiplin belajar yang tinggi di asrama akan mendapat presati yang baik pula sesuai hidup dan perjuangannya ${ }^{18}$.

Penerapan disiplin asrama memiliki pengaruh yang besar terhadap prestasi belajar dan hidup spiritual bagi anak yang bukan hanya untuk hari ini tetapi kelak akan menjadi seorang pemimpin yang disiplin dan tanggungjawab. Bagi anak yang memahami dan menerapkan disiplin belajar, disiplin hidup yang teratur akan mengganggap bahwa belajar merupakan sebuah kewajiban yang harus dilaksanakan dimana saja berada dan waktunya kapan saja dan belajar adalah satu hal yang sangat penting. Sebaliknya bagi anak yang mau hidup santai tanpa menerapkan disiplin belajar, tanpa memahami apa aturan bersama, yang hidup hanya ikut-ikutan saja tanpa memiliki prinsip pribadi yang jelas akan menganggap belajar merupakan sebuah paksaan atau karena tekanan dari faktor-faktor lain seperti paksaan dari orang tua, lingkungan, dan sekolah. Anak seperti ini akan hidup dalam ketekanan bathin, dan tidak memiliki tujuan hidup yang jelas dan hal sperti ini tidak akan bertahan lama.

Oleh karena itu, pengaruh penerapan disiplin belajar terhadap prestasi belajar anak di asrama sangat besar dan sifatnya tidak sementara, akan menjadi milik sampai kapan pun, dengan demikian penerapan disiplin dan aturan-aturan perlu di jelaskan sebelum menerapkan aturan-aturan agar anak memahami apa arti dari pengaruh disiplin. Dan apabila disiplin ini tidak didukung oleh orang tua di rumah, dan tanpa adanya kerja sama antara pemimpin asrama dan orang tua/wali maka semuanya tidak ada arti. Mengapa harus adanya dukungan dari orang tua, karena orang tua merupakan agen pendidikan anak yang utama dan pertama karena ibulah yang menanamkan disiplin sejak anak dalam kandungan ibu. Salah satu cara yang diberikan orang tua adalah memotivasi anak agar senantiasa menciptakan disiplin belajar baik di rumah, asrama maupun sekolah.

\subsection{Profil Asrama Puteri Sekolah Tinggi Pastoral Atma Reksa Ende}

\subsubsection{Latar Belakang}

Asrama (Latin: dormitorium) bukanlah sekadar bangunan yang menyediakan tempat tidur atau tempat tinggal untuk sejumlah besar orang yang hendak tinggal di dalamnya. Asrama pertama-tama merupakan "suasana", yang mana, setiap anggota saling memberi, saling melayani, dan saling mengalami kasih Allah sebagai satu komunitas. Asrama putri menampung anak putri dan asrama putra menampung anak putra.

${ }^{18}$ Gie The Liang., Cara Belajar yang Efisien. Yogyakarta: Pusat Kemajuan Studi-1988, hal. 60 
Asrama menyediakan tempat tidur, baik yang memiliki ruang hunian tunggal atau yang dialokasikan ke kamar yang berdekatan. Berbagai failitas diperlukan dalam sebuah asrama, misalnya, Internet, baik melalui koneksi jaringan di setiap ruang siswa, ruang cluster komputer pusat, atau Wi-Fi. Asrama tentu membebankan biaya makanan yang ditanggung anggota, entah makan secara bersama, berkelompok, atau sendiri-sendiri. Dengan demikian diperlukan fasilitas dapur. Selain itu perlu adanya fasilitas untuk belajar, rekreasi, olah raga, dan lainnya.

Yayasan Persekolahan St. Petrus coba membantu anggota asrama melalui berbagai program pendampingan dalam satu desain kurikulum nonformal. Dengan demikian, Pusat Pengembangan Kurikulum coba melihat secara serius, pola pendampingan nonformal maupun informal pada unit asrama dalam Yayasan Persekolahan Santu Petrus Ende dibawah Keuskupan Agung Ende.

\subsubsection{Tujuan}

Secara umum tujuan asrama adalah supaya para anggotanya memiliki kesempatan dan kondisi kondusif dalam mengembangkan potensi demi meningkatkan militansi kekatolikkan dengan fokus pada ranah afektif, psikomotorik, dan kognitif. Pertma, Supaya dapat mencapai tujuan (aims, goals, objectives) berasrama. Kedua, Mendesain konten yang hendak dikembangkan dalam asrama. Ketiga, Memiliki metode-metode pendampingan yang dipilih dilaksanakan. Keempat, Memiliki model evaluasi yang perlu dilakukan dalam asrama.

\subsubsection{Metode}

Karena penekanan pada militansi anggota asrama, maka metode yang digunakan dalam pendampingan asrama pada Yayasan Persekolahan Santu Petrus adalah metode-metode afektif. Dengan demikian, pendekatan dan strategi penanganan asrama lebih merupakan pendekatan dan strategi afektif. Kalau demikian, apakah ranah psikomotorik dan kognitif tidak diperlukan? Jawabannya: Tidak! Pertanyaan yang perlu diajukan lagi, yaitu di mana letak psikomotorik dan kognitif? Letak atau posisi ranah psikomotorik dan kognitif adalah sebagai "pelayan" bagi ranah afektif. Militansi berada pada ranah afektif. Namun kita membutuhkan kader-kader yang memiliki militansi yang terampil sekaligus mampu melakukan Higher Other Thinking Skills (mampu menganalisis atau mengevaluasi atau mencipta berbagai hal yang bermanfaat).

\subsubsection{Kajian Teori}

Di satu sisi Tyler memberikan pertanyaan-pertanyaan kunci dalam mendesain kurikulum, yaitu (1) apa tujuannya, (2) apa pilihan pengalaman belajar, (3) bagaimana memproseskan pengalaman belajar, (4) bagaimana evaluasinya. Di sisi lain, pertanyaan-pertanyan tersebut perlu dijawab dan dari jawaban itu, kita dapat menemukan gambaran mengenai desain kurikulum. Sehubungan dengan kurikulum asrama, kita dapat mengkaji lebih jauh ide dan gagasan Tyler tersebut.

Jika tujuan pendirian asrama berkaitan dengan melahirkan kader Gereja yang militan, maka segala sesuatu yang berkaiatan dengan pencapaian tersebut haruslah menjadi fokus ketika anggota asrama maupun pihak-pihak yang berkaitan dengan asrama mengimplementasikan kurikulum asrama. Jika pengalaman belajar hendak dipilih, maka pilihan pengalaman belajar haruslah mengacu pada pencapaian tujuan berasrama. Jika mengorganisir pengalaman untuk memaksimalkan efeknya merupakan hal yang penting dalam mencapai tujuan, maka pendekatan, strategi, dan metode perlu dipilih secara tepat. Jika kita ingin melihat sudah sejauh mana perkembangan militansi kader-kader tersebut, maka diperlukan model evaluasi yang pas.

Dari sudut pandang Benyamin Bloom, ada tiga ranah yang dapat membantu pendamping melihat kemajuan dan perkembangan seseorang, yakni afektif, kognitif, dan psikomotorik. Dari sudut pandang John Dewey, pengalaman belajar yang efektif perlu mempertimbangkan teori dan metode learning by doing atau belajar sambil berbuat. Pertanyaan yang dapat diajukan, yaitu bagaimana kita melihat pandangan dari kedua tokoh tersebut? Jika John Dewey memandang pentingnya pengalaman belajar 
dengan teori dan metode learning by doing atau belajar sambil berbuat, maka anggota asrama dapat dilihat dari persepektif keterampilan kerja (baik kerja tangan psikomorotik maupun kerja pikiran kognitif). Lalu bagaimana dengan ranah afektif? Teori dan metode learning by doing tetap menjadi "pelayan" yang melayani militansi anggota asrama. Contoh: Anggota asrama secara afektif "haruslah" militan dalam kedisiplinan. Itu berarti, belajar sambil berbuat dilakukan dengan "bangun di saat waktu masih subuh" atau "mengikuti misa dan ibadat" harus melayani "sikap iman" dan "kesadaran dalam menghargai" saat-saat itu.

Dalam pemikiran Bobbit, kurikulum perlu memperhatikan (1) kebutuhan individu, dan (2) kebutuhan masyarakat. Dalam pemikiran lain, Bobbit memberikan lima langkah pembuatan kurikulum, yaitu (1) analisis pengalaman manusia, (2) analisis pekerjaan, (3) menurunkan tujuan, (4) memilih tujuan, dan (5) perencanaan secara terperinci. Pertanyaan yang perlu diajukan, yaitu bagaimana menghubungkan gagasan Bobbit ini dengan pendampingan anggota asrama? Setiap orang cenderung mengusahakan pemenuhan akan kebutuhan, hal tersebut dapat dibandingkan dengan pemikiran Abraham Maslow. Diinspirasi dari pemikiran Bobbit, kurikulum yang baik akan mempertimbangkan kebutuhan masingmasing anggota asrama dalam mengembangkan dirinya. Walaupun demikian, pengembangkan diri perlu dikaitkan dengan apa yang dibutuhkan oleh masyarakat atau umat ketika anggota asrama telah tamat dari asrama tersebut. Untuk mencapai kedua kebutuhan tersebut, desain kurikulum perlu diawali dengan berbagai analisis atas kebutuhan-kebutuhan sebelum direncanakan dan diimplementasikan dalam keseluruhan proses kehidupan berasrama.

\subsubsection{Permasalahan yang dihadapi di asrama}

Permasalaha yang sekian sering terjadi secara umum di asrama; pertama, Boleh jadi kurangnya disiplin anggota asrama, kedua, Boleh jadi jnggota asrama belum menjadi teladan yang memberi contoh kehidupan yang tertib jikalau dibandingkan dengan anak yang tinggal di luar asrama. Ketiga, Boleh jadi sarana prasarana asrama yang belum memadai. Keempat, Belum adanya kerangka acuan atau kurikulum yang mempedomani aktivitas anggota asrama.

\subsection{Landasan Spiritual}

Kita mengenal istilah fides quae creditor, yaitu berkaitan dengan menerima iman. Kita mengenal istilah fides qua creditor, yaitu berkaitan dengan cara melakukan tindakan imani. Spiritualitas Katolik akan selalu dihubungkan dengan fides quae creditor dan fides qua creditor. Pertanyaan yang dapat diajukan, yaitu bagaimana kedua hal tersebut menjadi bagian integral dalam kehidupan para anggota asrama? Semua anggota asrama didampingi supaya memiliki semangat, baik untuk berdoa bersama di perayaan misa maupun dalam doa bersama, dan doa pribadi. Masing-masing anggota asrama perlu hidip dalam praktik spiritualitas untuk mendekatkan diri pada Tuhan dalam doa dan dalam hidup berdasarkan Injil.

\subsection{Landasan Sosial-Budaya}

Dalam kaitan dengan landasan sosial-budaya, kita perlu memberikan perhatian yang tinggi pada beragamnya kebudayaan para anggota asrama. Serentak dengan itu perlu disadari pentingnya upaya menghargai masing-masing budaya para anggota asrama dan budaya-budaya lainnya. Kurikulum pendampingan asrama perlu menyentuh aspek sosial budaya, supaya para anggota asrama tidak teralienasi dari kebudyaan dan kehidupan masyarakatnya sendiri.

\subsection{Landasan Sejarah Yayasan Persekolahan Santu Petrus Ende}

Yayasan Persekolahan Santu Petrus Ende hadir sebagai perpanjangan tangan Keuskupan Agung Ende dalam upaya menciptakan kader-kader katekis yang handal yang mencintai Allah dan berbakti kepada NKRI. 
Dalam kaitan dengan aspek sejarah, para anggota asrama perlu diperkenalkan dengan sejarah Yayasan Persekolahan Santu Petrus, unit-unit, sejarah leluhurnya sendiri, dan sejarah dirinya sendiri dalam berbagai kesempatan refleksi ataupun kegiatan lainnya.

\subsection{Landasan Yuridis}

Kitab Suci dan Kanon, Pancasila dan Undang - undang Dasar 1945, Undang - undang Sisdiknas berbicara tentang sistim pendidikan Nasional. Akte Notaris Yayasan Persekolahan Santu Petrus Ende, Anggaran Rumah tangga Yayasan Persekolahan Santu Petrus Ende, Pedoman-Pedoman turunan dari Anggaran Rumah Tangga Yayasan Persekolahan Santu Petrus Ende.

\subsection{Arah dan Jangkauan Peraturan dalam Asrama}

\subsubsection{Arah}

Membentuk kader-kader muda Katolik yang militan dalam afeksi yang didukung oleh keterampilan berpikir dan keterampilan berekspresi dengan kualitas yang handal. b) Membentuk kader-kader muda Katolik dengan sikap spiritual dan sosial-budaya yang dilandasi keberanian iman dan cinta yang bergerak (aktif). c) Membentuk kader-kader muda Katolik yang memiliki kerelaan menyumbang tenaga, pikiran, kemauan untuk menjadi saksi Injil sampai ke ujung dunia. d) Membentuk kader-kader muda Katolik yang mencintai NKRI ${ }^{19}$.

\subsubsection{Jangkauan peraturan}

Peraturan asrama disesuaikan dengan visi, misi, dan strategi Yayasan Persekolahan Santu Petrus Ende. b) Peraturan asrama disesuaikan dengan situasi dan kondisi sekolah formal. c) Peraturan asrama dibuat guna memudahkan aktivitas para anggota asrama supaya memperoleh militansi sebagai kader muda Katolik. d) Untuk tercapainya kedisiplinan belajar dapat didukung dengan aturan berupa jadwal harian seperti yang tercantum dibawah ini.

\section{JADWAL HARIAN}

ASRAMA PUTERI SEKOLAH TINGGI PASTORAL ATMA REKSA ENDE

\begin{tabular}{|c|c|c|c|}
\hline $\mathrm{NO}$ & JENIS KEGIATAN & WAKTU & KETERANGAN \\
\hline & \multicolumn{3}{|l|}{$\begin{array}{ll}\text { H A R I B I A S A } \\
\end{array}$} \\
\hline 1 & BANGUN PAGI & 05.00 & \\
\hline 2 & EKARISTI & $06.00-06.30$ & \\
\hline 3 & MAKAN PAGI & $06.30-07.00$ & \\
\hline 4 & $\begin{array}{r}\text { KAMPUS PAGI } \\
\text { SORE }\end{array}$ & $\begin{array}{l}07.45-13.30 \\
14.30-18.30\end{array}$ & \\
\hline 5 & MAKAN SIANG & $13.30-14.00$ & \\
\hline 6 & SIESTA & $14.00-15.30$ & \\
\hline 7 & BAKTI SORE & $16.00-17.00$ & \\
\hline 8 & KERJA TUGAS DAN MASAK & $17.00-17.30$ & \\
\hline 9 & DOA ROSARIO & $18.30-19.00$ & \\
\hline 10 & MAKAN MALAM & $19.00-19.30$ & \\
\hline 11 & BELAJAR & $20.00-22.00$ & \\
\hline 12 & DOA MALAM & 22.00 & $\begin{array}{l}\text { Di kelompok belajar masing- } \\
\text { masing }\end{array}$ \\
\hline \multirow[t]{2}{*}{13} & ISTIRAHAT MALAM & $22.00-05.00$ & \\
\hline & \multicolumn{3}{|c|}{ HARI MINGGU/ PESTA/LIBUR ATUR DIRI MASING - MASING (kecuali ada misa di kapel) } \\
\hline 1 & TERIMA TAMU: MINGGU & $\begin{array}{l}\text { PAGI } \\
\text { SORE }\end{array}$ & $\begin{array}{l}08.00-12.00 \\
15.30-17.30\end{array}$ \\
\hline 2 & TERIMA TAMU: SENIN- & SORE & $15.30-17.30$ \\
\hline
\end{tabular}

${ }^{19}$ Fransiskus S. Betu, Kurikulum Yayasan tentang Asrama dibawah naungan Yayasan St. Petrus Ende. 


\begin{tabular}{|l|l|l|l|}
\hline & SABTU & & \\
\hline 3 & OLAHRAGA & KAMIS, MINGGU & $15.30-16.30$ \\
\hline 4 & MALAM REKREASI & $\begin{array}{l}\text { MALAM MINGGU DAN } \\
\text { PESTA }\end{array}$ & $19.30-22.00$ \\
\hline
\end{tabular}

\section{Materi}

Materi atau konten dalam pendampingan anggota asrama bersifat afektif dan didukung oleh aspek psikomotorik dan kognitif. Adapun program kegiatan tahunan 2020/2021 meskipun dalam praktiknya ada kegiatan yang tidak dilaksanakan akibat pandemik covid-19 yang sedang melanda dunia sebagai berikut.

\section{ASRAMA PUTERI SEKOLAH TINGGI PASTORAL ATMA REKSA ENDE RENCANA KERJA TAHUN 2020/2021}

\section{a) PENDAhuluan}

Yayasan Persekolahan Santu Petrus dan Stipar memiliki fokus untuk pendampingan unit asrama pada masingmasing anggota asrama. Mahasiswi merupakan fokus yang coba mengembangkan diri dan difasilitasi oleh sekian banyak pihak demi mencapai pertama-tama penanaman militansi (afektif), selain aspek psikomotorik dan kognitif.

Rencana kerja ini merupakan salah satu cara yang coba dikemas untuk membantu anggota asrama putri Stipar.

b) RENCANA KERJA

\begin{tabular}{|c|c|c|c|c|c|c|c|c|}
\hline \multicolumn{9}{|c|}{ B ULA N S E P T E M B E R } \\
\hline No & $\begin{array}{l}\text { Hari/ } \\
\text { tgl }\end{array}$ & Program kegiatan & Sasaran & $\begin{array}{l}\text { Wak- } \\
\text { tu }\end{array}$ & $\begin{array}{l}\text { Penanggung- } \\
\text { jawab }\end{array}$ & Tempat & $\begin{array}{l}\text { Trans-- } \\
\text { port, } \\
\text { hadiah } \\
\text { Stipen- } \\
\text { dium }\end{array}$ & Ket \\
\hline 1 & Sabtu, & $\begin{array}{l}\text { Misa Asrama: } \\
\text { pembuka } \\
\text { Bulan Kitab Suci }\end{array}$ & $\begin{array}{l}\text { Asrama } \\
\text { Puteri } \\
\text { STIPAR } \\
\text { Ende }\end{array}$ & 18.00 & Seksi Liturgi & $\begin{array}{l}\text { Kapela } \\
\text { Asrama } \\
\text { STIPAR } \\
\text { Ende }\end{array}$ & $\begin{array}{l}\text { Rp. } \\
\text { 50.000,- }\end{array}$ & \\
\hline 2 & Sabtu, & $\begin{array}{l}\text { Lomba baca Kitab } \\
\text { Suci } \\
\text { Lomba paduan suara } \\
\text { antar tingkat }\end{array}$ & $\begin{array}{l}\text { Asrama } \\
\text { Puteri } \\
\text { STIPAR } \\
\text { Ende } \\
\end{array}$ & $\begin{array}{l}18.00 \\
- \\
\text { Sele- } \\
\text { sai } \\
\end{array}$ & $\begin{array}{l}\text { Para } \\
\text { pendamping } \\
\text { Seksi Liturgi }\end{array}$ & $\begin{array}{l}\text { Kapela } \\
\text { Asrama } \\
\text { STIPAR } \\
\text { Ende } \\
\end{array}$ & $\begin{array}{c}75.000 \\
50.000 \\
25.000\end{array}$ & \multirow{3}{*}{$\begin{array}{l}\text { Atau } \\
\text { buku } \\
\text { doa } \\
\text { dan } \\
\text { rosa- } \\
\text { rio }\end{array}$} \\
\hline 3 & Sabtu, & $\begin{array}{l}\text { Lomba Mazmur } \\
\text { tanggapan }\end{array}$ & $\begin{array}{l}\text { Asrama } \\
\text { Puteri } \\
\text { STIPAR } \\
\text { Ende }\end{array}$ & $\begin{array}{l}18.00 \\
- \\
\text { Sele- } \\
\text { sai }\end{array}$ & $\begin{array}{l}\text { Para } \\
\text { pendamping } \\
\text { Seksi Liturgi }\end{array}$ & $\begin{array}{l}\text { Kapela } \\
\text { Asrama } \\
\text { STIPAR } \\
\text { Ende }\end{array}$ & $\begin{array}{l}75.000 \\
50.000 \\
25.000\end{array}$ & \\
\hline 4 & Sabtu, & $\begin{array}{l}\text { Lomba Kuis Kitab } \\
\text { Suci } \\
\text { Lomba dramatisasi } \\
\text { Kitab Suci }\end{array}$ & $\begin{array}{l}\text { Asrama } \\
\text { Puteri } \\
\text { STIPAR } \\
\text { Ende } \\
\end{array}$ & $\begin{array}{l}18.00 \\
- \\
\text { Sele- } \\
\text { sai } \\
\end{array}$ & $\begin{array}{l}\text { Para } \\
\text { pendamping } \\
\text { Seksi Liturgi }\end{array}$ & $\begin{array}{l}\text { Kapela } \\
\text { Asrama } \\
\text { STIPAR } \\
\text { Ende } \\
\end{array}$ & $\begin{array}{l}75.000 \\
50.000 \\
25.000\end{array}$ & \\
\hline \multicolumn{9}{|c|}{ B U L A N OK T OB ER } \\
\hline 1 & $\begin{array}{l}\text { Kamis, } \\
01\end{array}$ & $\begin{array}{l}\text { Misa pembukaan } \\
\text { Bulan Rosario }\end{array}$ & $\begin{array}{l}\text { Asrama } \\
\text { Puteri } \\
\text { STIPAR } \\
\text { Ende }\end{array}$ & $\begin{array}{l}18.00 \\
- \\
\text { Seles } \\
\text { ai }\end{array}$ & $\begin{array}{l}\text { Para } \\
\text { pendamping } \\
\text { Seksi Liturgi }\end{array}$ & $\begin{array}{l}\text { Kapela } \\
\text { Asrama } \\
\text { STIPAR } \\
\text { Ende }\end{array}$ & $\begin{array}{l}\text { Rp. } \\
50.000,-\end{array}$ & \\
\hline 2 & $02-30$ & Doa Rosario Bersama & $\begin{array}{l}\text { Asrama } \\
\text { Puteri } \\
\text { STIPAR }\end{array}$ & $\begin{array}{l}18.00 \\
- \\
\text { Sele- }\end{array}$ & $\begin{array}{l}\text { Para } \\
\text { pendamping } \\
\text { Seksi Liturgi }\end{array}$ & $\begin{array}{l}\text { Kapela } \\
\text { Asrama } \\
\text { STIPAR }\end{array}$ & & $\begin{array}{l}\text { Ko- } \\
\text { muni- } \\
\text { tas }\end{array}$ \\
\hline
\end{tabular}




\begin{tabular}{|c|c|c|c|c|c|c|c|c|}
\hline & & & Ende & sai & & Ende & & \\
\hline 3 & $\begin{array}{l}\text { Sabtu, } \\
31\end{array}$ & Ziarah bersama & $\begin{array}{l}\text { Asrama } \\
\text { Puteri } \\
\text { STIPAR } \\
\text { Ende } \\
\end{array}$ & & $\begin{array}{l}\text { Para } \\
\text { pendamping } \\
\text { Seksi Liturgi }\end{array}$ & & 50.000 & \\
\hline \multicolumn{9}{|c|}{ B ULA N NOPEMB ER } \\
\hline 1 & $\begin{array}{l}\text { Mingg } \\
\mathrm{u}, 01\end{array}$ & $\begin{array}{l}\text { Pesta Orang Kudus } \\
\text { (Ekaristi) }\end{array}$ & $\begin{array}{l}\text { Asrama } \\
\text { Puteri } \\
\text { STIPAR } \\
\text { Ende }\end{array}$ & & $\begin{array}{l}\text { Para } \\
\text { pendamping } \\
\text { Seksi Liturgi }\end{array}$ & $\begin{array}{l}\text { Kapela } \\
\text { Asrama } \\
\text { STIPAR } \\
\text { Ende }\end{array}$ & 50.000 & \\
\hline 2 & $\begin{array}{l}\text { Senin, } \\
02\end{array}$ & $\begin{array}{l}\text { Peringatan Arwah } \\
\text { (Ekaristi) }\end{array}$ & $\begin{array}{l}\text { Asrama } \\
\text { Puteri } \\
\text { STIPAR } \\
\text { Ende }\end{array}$ & & $\begin{array}{l}\text { Para } \\
\text { pendamping } \\
\text { Seksi Liturgi }\end{array}$ & $\begin{array}{l}\text { Kapela } \\
\text { Asrama } \\
\text { STIPAR } \\
\text { Ende }\end{array}$ & & \\
\hline 3 & $\begin{array}{l}\text { Jumat, } \\
13\end{array}$ & $\begin{array}{l}\text { Latihan Ibadat Sabda } \\
\text { tanpa Imam }\end{array}$ & $\begin{array}{l}\text { Asrama } \\
\text { Puteri } \\
\text { STIPAR } \\
\text { Ende }\end{array}$ & $\begin{array}{l}18.00 \\
- \\
\text { Sele- } \\
\text { sai }\end{array}$ & $\begin{array}{l}\text { Para } \\
\text { pendamping } \\
\text { Seksi Liturgi }\end{array}$ & $\begin{array}{l}\text { Kapela } \\
\text { Asrama } \\
\text { STIPAR } \\
\text { Ende }\end{array}$ & 50.000 & \\
\hline 4 & $\begin{array}{l}\text { Sabtu, } \\
21\end{array}$ & Pelatihan MC & $\begin{array}{l}\text { Asrama } \\
\text { Puteri } \\
\text { STIPAR } \\
\text { Ende }\end{array}$ & $\begin{array}{l}18.00 \\
- \\
\text { Seles } \\
\text { ai }\end{array}$ & & $\begin{array}{l}\text { Aula } \\
\text { Asrama } \\
\text { STIPAR } \\
\text { Ende }\end{array}$ & 50.000 & \\
\hline \multicolumn{9}{|c|}{ B U L A N DE S E M B E R } \\
\hline 1 & $\begin{array}{l}\text { Sabtu, } \\
12\end{array}$ & $\begin{array}{l}\text { Rekoleksi } \\
\text { Ibadat } \\
\text { Tobat/Pengakuan } \\
\text { Dosa } \\
\end{array}$ & $\begin{array}{l}\text { Asrama } \\
\text { Puteri } \\
\text { STIPAR } \\
\text { Ende }\end{array}$ & $\begin{array}{l}16.00 \\
\text {-sele- } \\
\text { sai }\end{array}$ & $\begin{array}{l}\text { Para } \\
\text { pendamping } \\
\text { Seksi Liturgi }\end{array}$ & $\begin{array}{l}\text { Kapela } \\
\text { Asrama } \\
\text { STIPAR } \\
\text { Ende }\end{array}$ & 100.000 & \\
\hline 2 & & UAS & \multicolumn{5}{|c|}{ LE M B A G A } & \\
\hline 3 & $\begin{array}{l}\text { Selasa, } \\
20\end{array}$ & Asistensi Natal & \multicolumn{6}{|c|}{$L E M B A G A$} \\
\hline \multicolumn{9}{|c|}{$\begin{array}{ll}\text { J A N A R I } & 2021 \\
\end{array}$} \\
\hline 1 & $\begin{array}{l}\text { Sabtu, } \\
09\end{array}$ & $\begin{array}{l}\text { Misa Natalan } \\
\text { bersama } \\
\text { Tukar Kado Rp. } \\
25.000\end{array}$ & $\begin{array}{l}\text { Asrama } \\
\text { Puteri } \\
\text { STIPAR } \\
\text { Ende }\end{array}$ & $\begin{array}{l}17.30 \\
- \\
\text { Sele- } \\
\text { sai }\end{array}$ & $\begin{array}{l}\text { Para } \\
\text { pendamping } \\
\text { Seksi Liturgi }\end{array}$ & $\begin{array}{l}\text { Kapela } \\
\text { Asrama } \\
\text { STIPAR } \\
\text { Ende }\end{array}$ & $\begin{array}{l}500.000 \\
\text { (KONSU } \\
\text { MSI) }\end{array}$ & \\
\hline 2 & $\begin{array}{l}\text { Sabtu, } \\
23\end{array}$ & $\begin{array}{l}\text { Pelatihan Dirigen, } \\
\text { Mazmur Tanggapan }\end{array}$ & Semester VI & $\begin{array}{l}18.00 \\
- \\
\text { Sele- } \\
\text { sai }\end{array}$ & $\begin{array}{l}\text { Para } \\
\text { pendamping } \\
\text { Seksi Liturgi }\end{array}$ & $\begin{array}{l}\text { Aula } \\
\text { Asrama } \\
\text { SIPAR } \\
\text { ENDE } \\
\end{array}$ & 50.000 & \\
\hline \multicolumn{9}{|c|}{ B U L A N FEB R U A R I } \\
\hline 1 & $\begin{array}{l}\text { Sabtu, } \\
13\end{array}$ & $\begin{array}{l}\text { Pembinaan Rohani } \\
\text { Tema: Jati diri } \\
\text { seorang Katekis } \\
\text { dalam Persahabatan }\end{array}$ & $\begin{array}{l}\text { Asrama } \\
\text { Puteri } \\
\text { STIPAR } \\
\text { Ende }\end{array}$ & $\begin{array}{l}18.00 \\
- \\
\text { Sele- } \\
\text { sai }\end{array}$ & $\begin{array}{l}\text { Para } \\
\text { pendamping } \\
\text { Seksi Liturgi }\end{array}$ & $\begin{array}{l}\text { Aula } \\
\text { Asrama } \\
\text { SIPAR } \\
\text { ENDE }\end{array}$ & 50.000 & \\
\hline 2 & $\begin{array}{l}\text { Sabtu, } \\
20\end{array}$ & Latihan Koor & $\begin{array}{l}\text { Asrama } \\
\text { Puteri } \\
\text { STIPAR } \\
\text { Ende } \\
\end{array}$ & $\begin{array}{l}18.00 \\
- \\
\text { Sele- } \\
\text { sai } \\
\end{array}$ & $\begin{array}{l}\text { Para } \\
\text { pendamping } \\
\text { Seksi Liturgi }\end{array}$ & $\begin{array}{l}\text { Aula } \\
\text { Asrama } \\
\text { SIPAR } \\
\text { ENDE } \\
\end{array}$ & & \\
\hline
\end{tabular}




\begin{tabular}{|c|c|c|c|c|c|c|c|}
\hline 1 & $\begin{array}{l}\text { Sabtu, } \\
13\end{array}$ & $\begin{array}{l}\text { Pelatihan: } \\
\text { Kepemimpinan }\end{array}$ & $\begin{array}{l}\text { Asrama } \\
\text { Puteri } \\
\text { STIPAR } \\
\text { Ende }\end{array}$ & $\begin{array}{l}19.00 \\
- \\
\text { Sele- } \\
\text { sai }\end{array}$ & $\begin{array}{l}\text { Para pendamping } \\
\text { Seksi Liturgi }\end{array}$ & $\begin{array}{l}\text { Aula } \\
\text { Asrama } \\
\text { SIPAR } \\
\text { ENDE }\end{array}$ & $50.000,-$ \\
\hline \multirow[t]{2}{*}{2} & $\begin{array}{l}\text { Sabtu } \\
20\end{array}$ & Katekese APP & $\begin{array}{l}\text { Asrama } \\
\text { Puteri } \\
\text { STIPAR } \\
\text { Ende }\end{array}$ & $\begin{array}{l}18.00 \\
- \\
\text { Sele- } \\
\text { sai }\end{array}$ & $\begin{array}{l}\text { Para pendamping } \\
\text { Seksi Liturgi }\end{array}$ & $\begin{array}{l}\text { Aula } \\
\text { Asrama } \\
\text { SIPAR } \\
\text { ENDE }\end{array}$ & \\
\hline & & $\begin{array}{l}\text { Rekoleksi Paskah/ } \\
\text { Sakremen Tobat }\end{array}$ & $\begin{array}{l}\text { Asrama } \\
\text { Puteri } \\
\text { STIPAR } \\
\text { Ende }\end{array}$ & $\begin{array}{l}16.00 \\
- \\
\text { Seles } \\
\text { ai } \\
\end{array}$ & $\begin{array}{l}\text { Para pendamping } \\
\text { Seksi Liturgi }\end{array}$ & $\begin{array}{l}\text { Kapela } \\
\text { Asrama } \\
\text { STIPAR } \\
\text { Ende }\end{array}$ & $100.000,-$ \\
\hline \multicolumn{8}{|c|}{ B U L A N A P R I L } \\
\hline 1 & $\begin{array}{l}\text { Sabtu } \\
24\end{array}$ & $\begin{array}{l}\text { - Pembinaan Rohani } \\
\text { Tema: Siapakah Saya }\end{array}$ & $\begin{array}{l}\text { Asrama } \\
\text { Puteri } \\
\text { STIPAR } \\
\text { Ende }\end{array}$ & $\begin{array}{l}18.00 \\
- \\
\text { Sele- } \\
\text { sai }\end{array}$ & $\begin{array}{l}\text { Para pendamping } \\
\text { Seksi Liturgi }\end{array}$ & $\begin{array}{l}\text { Aula } \\
\text { Asrama } \\
\text { SIPAR } \\
\text { ENDE }\end{array}$ & 50.000 \\
\hline \multicolumn{8}{|c|}{ B ULA N M E I } \\
\hline 1 & $\begin{array}{l}\text { Sabtu, } \\
01\end{array}$ & $\begin{array}{l}\text { Misa Pembuka Bulan } \\
\text { Maria }\end{array}$ & $\begin{array}{l}\text { Asrama } \\
\text { Puteri } \\
\text { STIPAR } \\
\text { Ende }\end{array}$ & $\begin{array}{l}18.00 \\
- \\
\text { Sele- } \\
\text { sai }\end{array}$ & $\begin{array}{l}\text { Para pendamping } \\
\text { Seksi Liturgi }\end{array}$ & $\begin{array}{l}\text { Gua Maria } \\
\text { CIJ } \\
\text { Potunggo- } \\
\text { Ende }\end{array}$ & 50.000 \\
\hline 2 & $\begin{array}{l}\text { Sabtu, } \\
15\end{array}$ & $\begin{array}{l}\text { Pelatihan } \\
\text { Administrasi } \\
\text { Keuangan }\end{array}$ & Semester VI & $\begin{array}{l}18.00 \\
- \\
\text { Seles } \\
\text { ai } \\
\end{array}$ & & $\begin{array}{l}\text { Aula } \\
\text { Asrama } \\
\text { STIPAR } \\
\text { Ende }\end{array}$ & 50.000 \\
\hline \multicolumn{8}{|c|}{ B U L A N J U N I } \\
\hline 1 & & $U A S$ & & & & & \\
\hline 2 & 29 & $\begin{array}{l}\text { Pesta Pelindung } \\
\text { Yayasan dan Asrama }\end{array}$ & $\begin{array}{l}\text { Asrama } \\
\text { Puteri } \\
\text { STIPAR } \\
\text { Ende }\end{array}$ & $\begin{array}{l}18.00 \\
- \\
\text { Sele- } \\
\text { sai }\end{array}$ & $\begin{array}{l}\text { Para pendamping } \\
\text { Seksi Liturgi }\end{array}$ & $\begin{array}{l}\text { Kapela } \\
\text { Asrama } \\
\text { STIPAR } \\
\text { Ende }\end{array}$ & 50.000 \\
\hline
\end{tabular}

Mengetahui

Ketua STIPAR ATMA REKSA ENDE
Ende, 2020

Pendamping Asrama

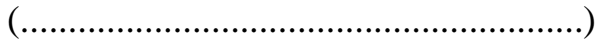

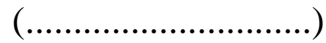

\section{Kesimpulan}

Dampak dari pengaruh penerapan disiplin belajar terhadap mahasiswi asrama puteri Sekolah Tinggi Pastoral Atma Reksa Ende, sangat berpengaruh terhadap keberhasilan akademik, kematangan hidup spiritual dan lebih dari itu adalah mahasiswi dapat belajar untuk mulai membentuk dan memroses secara individu dalam mempersiapkan diri menyongsong masa depan yang baik dan mandiri. Selain itu mahasiswi berhasil dalam menghadapi segala macam tantangan, termasuk tantangan untuk berhasil secara akademis.

Pengaruh penerapan disiplin di asrama pun memiliki faktor - faktor yang positf yakni mendidik anak memiliki rasa percaya diri, kemampun bekerja sama, kemampuan bergaul, kemampuan berkonsentrasi, rasa empati, kemampuan bersolidaritas dan kemampuan berkomunikasi. Untuk mencapai tujuan penerapan disiplin mahasiswi di asrama, perlu ditunjang oleh; pertama, aturan-aturan yang 
mendukung, program-program kegiatan bulanan yang melibatkan partisipasi aktif mahasiswi, meningkatkan motivasi mahasiswi, orang tua, lingkungan dan kurikulum asrama. Kedua, menciptakan lingkungan belajar yang kondusif (conducive learning community) sehingga mahasiswi dapat belajar dengan efektif dan tetap memberikan semangat. Ketiga, metode pendampingan di asrama lebih memperhatikan keunikan masing-masing mahasiswi, yakni menerapkan kurikulum yang melibatkan aspek solidaritas dan kebersamaan untuk mencapai individu yang disiplin, tanggung jawab, jujur bermoral, dan bertaqwa.

\section{DAFTAR PUSTAKA}

Betu, Fransiskus Soda. 2010. Kurikulum Asrama Yayasan St. Petrus Ende

Hamid D. 2010. Kemampuan Dasar Mengajar Landasan Konsep dan Implementasi, Bandung: Alfabeta

Haryanto. 2010. Pengertian Prestasi Belajar. http://belajarpsikologi.com/pengertian-prestasi-belajar/. Diunduh di Ende, 10 Januari 2021.

http://mariatulannisa.blogspot.com/2014/01/teori-prestasi-belajar.html. Diakses di Ende, 20 Januari 2021.

Hurlock, Elizabeth B. 2008. Psikologi Perkembangan Suatu Pendekatan Sepanjang Rentang Kehidupan (Edisi 5) 1980. Diterjemahkan oleh Istiwidayanti dan Soedjarwo. Jakarta: Erlangga. 99, 129.

Muslich M. 2015. Pendidikan Karakter, Menjawab Tantangan Krisis Multidimensional, PT Bumi Aksara, 2015

Oemar H. 2001. Proses Belajar Mengajar, Bandung: Remaja Rosdakarya

Slameto. 2010. Belajar dan Faktor-faktor yang Mempengaruhinya Jakarta: Rineka Cipta

Suharno. 2011. Pengaruh Disiplin Belajar terhadap Prestasi Belajar Mata Pelajaran Fiqih Siswa kelas V di SD Islam Darul Falah Genuk Semarang. Skripsi. Institut Agama Islam Negeri Walisongo Semarang

Suharsimi A. 2013. Dasar-dasar Evaluasi Pendidikan, Jakarta: Rineka Cipta

Tulus T. 2004. Peran Disiplin pada Perilaku dan Prestasi Siswa, Jakarta: Grasindo

The Liang G. 1988. Cara Belajar yang Efisien. Yogyakarta: Pusat Kemajuan Studi 